\title{
Social Action of Conversion in Islamic Art: Study on the Laras- madya Art Form in the Sleman Geocultural Region
}

\author{
Sutiyono \\ Received: 04032015 / Accepted: 06042015 / Published online: 30 june 2015 \\ (c) 2015 Faculty of Geography UGM and The Indonesian Geographers Association
}

\begin{abstract}
The research concerned here had the purpose of learning the rationality in the social action of conversion by the farmer communities supporting the Larasmadya art form in the Sleman geocultural region. The research was qualitative in approach. The research subjects were members of the farmer communities supporting the Larasmadya art who previously supporting the Slawatan Maulud art form. The research data were compiled by means of observations, interviews, and documentation. These data were analyzed through the phases of data collection, data reduction, data examination, and drawing the conclusion. Data validation was done by means of triangulation. The research results in relation with rationality in the social action of conversion by the communities supporting the Larasmadya art form in the Sleman geocultural region indicate the following. (1) The Larasmadya art form uses the text called Serat Wulang Reh. The text contains Javanese songs influenced by Islam. In addition, the text of the songs in the Larasmadya art form depicts the life of the farmer communities supporting the Larasmadya art form in the Sleman geocultural region. (2) The presence of the Larasmadya art form implies a process of making Islam native in the Sleman geocultural region.
\end{abstract}

Keywords: Larasmadya, social action, conversion, geocultural Sleman.

Abstrak Penelitian ini bertujuan untuk mengetahui rasionalitas tindakan sosial konversi masyarakat petani pendukung Seni Larasmadya di wilayah geokultural Sleman. Pendekatan penelitian yang dipergunakan adalah pendekatan kualitatif. Subjek penelitian ini adalah masyarakat petani pendukung seni Larasmadya yang dulunya sebagai pendukung seni Slawatan Maulud. Cara pengumpulan data dengan: observasi, wawancara, dan dokumentasi. Data penelitian dianalisis dengan tahapan: koleksi data, reduksi data, pemeriksaan data, dan penarikan kesimpulan. Pengabsahan data dilakukan dengan triangulasi. Hasil penelitian ini menunjukkan bahwa rasionalitas tindakan sosial konversi masyarakat pendukung Seni Larasmadya di wilayah geokultural Sleman, yaitu: (1) Seni Larasmadya mempergunakan teks Serat Wulang Reh. Serat ini berisi tentang tembang-tembang Jawa yang bernafaskan agama Islam. Selain itu, teks tembang-tembang dalam seni Larasmadya menggambarkan kehidupan masyarakat petani pendukung seni Larasmadya di wilayah geokultural Sleman. (2) Hadirnya seni Larasmadya memberikan makna sebagai proses pribumisasi Islam di wilayah geokultural Sleman.

Kata kunci: Larasmadya, tindakan sosial, konversi, geokultural Sleman.

\section{Introduction}

In the Sleman region, there are many art forms having an Islamic nature. The Islamic nature is indicated by, among others, the use of the musical instrument called terbang or rebana accompanying vocal text containing Islamic hymns or elements of dakwah (preaching). Thus, they are performing art forms using musical elements and they are, among others, called Badui, Santiswara, Larasmadya, Emprak, Kobrasiswa, Angguk, Dolalak, Mondreng, Rodat, Slawatan Maulud, Berjanjen, Samroh, Hadroh, Kuntulan, and Trengganon. All these art forms, whether they are dramatic, dance, or musical art forms, are Javanese art forms showing the influence of Islam. Murgiyanto [1993] says that the Islamic influence in the Indonesian performance arts with musical elements is felt through two aspects: content or message and instrument.

\section{Sutiyono}

Faculty of Language and Arts, Yogyakarta State University

Email: Sutiyonouny@yahoo.com
At first, the type of Javanese performance art using terbang as its musical intrument was called Slawatan. However, when it spread and developed from region to region, each region showing the influence of Islam varies in name but remains uniform in musical instrument [Soedarsono, 1994]. Basically, the Islamic nature only goes as far as load or content in a Javanese art form because the dramatic, dance, and musical technique itself is not present in Islam. The varieties of movement in the dances called Badui, Trengganon, Japin, Angguk, and others have not been shaped through Islamic norms. The Macapat chorus in the Larasmadya and Santiswara music is not any vocal originating in Islam. The art form called Srandhul, a folk drama incorporating elements of dakwah into it self, is not a dramatic art form shaped through Islamic dramatic concepts. Thus, all the above art forms are Javanese art forms having inserted Islamic messages or containing elements of dakwah.

A form of performance art is said to contain elements of dakwah when it contains invitations to behave in accordance with the rules of Islam by being 
fearful of God, by being dutiful to people considered older, by inviting others to pray, by emulating the actions of the Prophet Muhammad, and so on. In addition, the reading of verses from the holy book Al Qur'an, the utterance of greeting and sholawat to the Prophet Muhammad are all found in Islamic Javanese arts. These performance forms bearing messages of being Islamic have lasted for generations [Sedyawati, 1995]. And they have their own supporting communities in their respective regions. Therefore, these art forms count as included in the treasury of traditional arts in existence in the Sleman geocultural region.

The communities supporting the traditional arts in the Sleman geocultural region frequently take the social action of conversion or transfer from one genre of art to another for a certain purpose. Performers in some traditional arts have been known to make a conversion to some other traditional arts. Some of them have made a conversion from Wayang Wong Purbawanara to Jathilan, from Karawitan to Campursari, from Kethoprak to Wayang Kulit, from Samroh to Hadroh, and from Slawatan Maulud to Larasmadya, for example.

Parsons [1974] mentions that social action has a social framework. The framework is a schema consisting of five basic elements, namely, (1) the actor, who acts deliberately and with awareness, (2) the goal, which is the place to which the actor's action is directed, (3) the means, which is the instrument for achieving the goal, (4) the value orientation, which makes the actor determine the choice and goal of doing the social action, and (5) the actor's biological condition and social situation. These five elements influence each other in a certain sense. Each actor taking a social action has a consciousness also influenced by the biological condition and social situation of the actor concerned. That is not the end of the matter because an actor taking a social action is also influenced by the means that the actor would choose to achieve the goal of the social action. The goal would of course exert an influence on the value orientation attached to the actor. On that basis, a research was made on the social action of conversion in Islamic arts, specifically that made by the communities supporting the Slawatan Maulud art form who had made a conversion to the Larasmadya art form. The social action of conversion taken by the performers of the Larasmadya art form who were originally performers of the Slawatan Maulud art form certainly implies a rational choice of its own.

Of course the rational choice depends on the actor. The actor is considered having a purpose. In doing a social action, the actor uses the ends and goals as the place to which the action is directed [Heckathorn, 2001]. In addition, the actor also has preferences so that the action the actor takes in achieving the purpose is already in accordance with the preferences the actor has. The rational choice is made by using the consideration of maximizing the profit obtained from a social action in a situation in which there are many obstructions.
Whatever is the case, generally the important thing is to have ease instead of difficulty whenever possible. For example, for the Javanese, it would be a rational choice to become members of the communities supporting the Larasmadya art form because reading a text which is in Javanese would be easier than reading a text of the Slawatan Maulud art form, which is in Arabic. Thus, they choose the Larasmadya art form because they feel that they would more easily get something considered able to give a contribution to their life. As Marshall [Waters, 1994] reveals, one would always like to get what one wants as easily as possible and it is considered something rational.

The social action of conversion in art form by these performers of an Islamic art form implies a change of behavior in performing the arts. Within artistic aspects, there is a dimension of consequence as well as a dimension of rationality, in the sense of why a number of people who previously enjoyed and performed the Slawatan Maulud art form have now moved to the Larasmadya art form. The rationale has once been presented by Weber [in Morrison, 1995], namely, they could take a social action by considering what they think in choosing the right means to achieve the goal. Of course the rationality has a number of arguments as well as social situations and conditions influencing the social action.

In any case, the conversion action has caused many social phenomena to arise. The reason is that no regeneration had occurred yet among the performers of the Slawatan Maulud art form when many of them moved to the groups performing the Larasmadya art form. As a result, the number of groups performing the Slawatan Maulud art form has been decreased while replacements for the performers who had moved are not yet available and this, in turn, would possibly cause the Slawatan Maulud art form to eventually become extinct. he problem under the empirical study concerned here was not that of regeneration among performers of the Slawatan Maulud art form. The most important area of study in this research is the aspect of rationality in the social action of conversion by the performers of the Larasmadya art form, who were originally performers of the Slawatan Maulud art form and the hidden meaning behind the aforementioned social action of conversions. Therefore, the objective of the research is to determine the rationality of the social action of conversion having done by performers of the Larasmadya art form in the Sleman geocultural region.

\section{The Methods}

The research relied on the qualitative approach. The Sleman Regency or, more specifically, its subdistricts in its central and western regions, namely, the subditricts of: Prambanan, Cangkringan, Berbah, Sleman, Turi, Tempel, Ngaglik, Pakem, Mlati, Gamping, Seyegan, Godean, Minggir, and Moyudan, became the geocultural region chosen to be the research location 
(Figure 1). In that geocultural region, there have been many performers of Islamic art forms experiencing the action of conversion in form from the Slawatan Maulud art form to the Larasmadya art form.

The research data were compiled by means of observations, interviews, and documentation. By means of observations, the researcher could see the dance art teaching and learning process. By means of interviews, the researcher could reveal how the research subjects interpreted or gave meaning to the dance art teaching and learning process. By means of documentation, the researcher could gather and place the terminology and sources of the research theories of teaching and learning and of humanization.

The data compiled through observations, interviews, and documentation above were qualitative in nature. The data were analyzed descriptively and interpretatively through the following steps: (1) choosing relevant documents or data and giving them codes, (2) making objective notes and in this case simultaneously classifying and editing (or reducing) responses, (3) making reflective notes by putting down in writing what the researcher was thinking of as interpretation in relation with the objective notes, (4) drawing conclusions of the data by making a format based on the technique of data analysis desired, and (5) making a triangulation, which was checking the data validity by drawing conclusions of multiple data obtained in three ways, namely, (1) extending the observation time in the field for the purpose of checking the written data with the field data, (2) checking the written data with the informants by asking them questions again, and (3) checking the written data with sources from the literature.

\section{Result anda Discussion}

The origin of the name Sleman, according to Poerbatjaraka [Suwarno, 2002], began with a forest named Kunjarakenya Desa, which was a forest región for elephants. In Old Javanese such a forest is called alasing liman. The word liman, which refers to elephants, then developed into the word saliman, which has eventually become the one used as the name Sleman until now. This interpretation is strengthened with the discovery of a prasasti (memorial stone) called Saliman IV with an inscription carved on it about the establishment of the perdikan (autonomous tax-exempt region) of the Saliman forest (around the present Demangan) in 802 Saka Year or 880 A.D. The Sleman region is very wide and it is part of the land at the foot of Mount Merapi. From the northen zone to the south and from the eastern zone to the west lie wide fields of rice plants with abundant irrigation, even starting to ascend to the slopes of Mount Merapi, whose periodic eruptions deliver disastrous hot lava but simultaneously bring fertility to the land in Sleman. Various rice, corn, pepper, salak pondoh, vegetable, tobacco, and watermelon plants grow well in the fertile soil.
Geographically, Sleman is located in the south of Mount Merapi (Figure 1). The Sleman regency shares borders with the Magelang regency to the north, the Bantul regency to the south, the Kulonprogo regency to the west, and the Klaten and the Gunungkidul regncy to the east [BPS Kabupaten Sleman, 2014]. Therefore, Sleman is a administratively located within the the Special Region of Yogyakarta

The people living in Sleman are mostly Javanese. They have been living in the central and eastern territories of Java Island for generations. In daily life they use Javanese language with various dialects. The Sleman region is considered a kejawen area, like the Kedu, Yogyakarta, Surakarta, and Madiun regions. The other regions in Java are called Pesisir and Ujung Timur [Koentjaraningrat, 1990].

Geographically, Sleman regency is located between $110^{\circ} 33^{\prime} 00^{\prime \prime}$ and $110^{\circ} 13^{\prime} 00^{\prime \prime}$ Eastern Longitude and between $7^{\circ} 34^{\prime} 51^{\prime \prime}$ and $7^{\circ} 47^{\prime} 30^{\prime \prime}$ Southern Latitude. The Sleman region is often called Bumi Merapi (or Merapi Ground) because almost all the land are situated on foot of Mount Merapi. The southern part of the land in the Sleman regency is relatively flat, except the hills area in the southeastern part of Prambanan subdistrict and in a part of Gamping subditrict,. The northern region is dominated by steep slope topography and there are a lot of water spring. Almost half the area is fertile farmland supported by irrigation in the western and southern parts through an technical facility in the form of a channel named Selokan Mataram (or the Mataram Ditch). In addition, in the Sleman region there are several rivers that are passsing through, contributing fertility to the land; the names of the rivers are Kali Progo, Kali Code, Kali Kuning, Kali Krasak, and Kali Opak.

The total area Sleman regency is $57,482 \mathrm{Ha}$ or $574.82 \mathrm{Km} 2$. The dominant landuse type can be divided into sawahs (rice-growing wet fields), tegalans (dry fields), yards, forests, and so on. The landuse development within the last five years indicates that each year on the average the sawah land type decreases by $0.96 \%$, the tegalan land type increases by $0.82 \%$, the yard land type increases by $0.31 \%$, and others decrease by $1.57 \%$ (http://www.bpkp.go.id/diy/konten/ $830 /$ Profil-Kabupaten-Sleman).

According to records in 2013, the population of the Sleman regency is $1,141,718$, consisting of 574,913 males and 566,805 females within an area of 574.82 square kilometers. On the average, the population density in the Sleman regency is $1,986 / \mathrm{km} 2$ [BPS Kabupaten Sleman, 2014]. Sleman is also called the rice storehouse of the Special Region of Yogyakarta. Thus, the Sleman region is one of the agrarian ones. Agrarian communities are usually related to the life of traditional culture. They work in the fields growing rice by day and entertain themselves with traditional art forms by night.

Culturally, Sleman occupies a unique position in the framework of Mataram Javanese culture. Because 
Sleman is part of the territory of the Special Region of Yogyakarta and at the same time faces the Central Java Province on the opposite side of the border, it lies between two great cultures in Java island, namely, the Javanese culture centered at Kraton Kasunanan Surakarta (the palace of Surakarta Kingdom), , and the Javanese culture centered at Kraton Kasultanan Yogyakarta (the palace of Yogyakarta Kingdom)

Historically and sociologically, Sleman region is a border region whose inhabitants reflect the family relationship between Kraton Kasultanan Yogyakarta and Kraton Kasunanan Surakarta. However, Sleman is also the place for the Surakarta and Yogyakarta cultural traffic to pass through. Moreover, Sleman is a gateway for the entrance of culture from outside and especially from the geocultural region of Central Java. In the northwest, Sleman shares border with Magelang District, thus allowing traditional dances from Magelang such as Topeng Ireng and Dayakan to enter the Sleman geocultural region. Likewise, in the eastern part, Sleman shares border with Klaten District, thus allowing performance art forms such as wayang kulit, karawitan, and Larasmadya to also enter Sleman geocultural region.

As discussed previously, the Larasmadya art form in the Sleman geocultural region originated from Surakarta. At first, the dissemination of the Larasmadya art form in Sleman, , was attributed to a mubaligh (moslim preacher) named Moh. Salman. He was born in Kauman, Surakarta, in 1919. At the age of 17 years, together with eight of his friends, he began studying and learning the Larasmadya art form from Prabu Winoto, who was a younger brother of Paku Buwono X, ruler of Kraton Kasunanan Surakarta (1893-1939). After being considered having sufficiently learned reading and studying the Islamic holy book and skillful in performing the Larasmadya art form, he was asked by Prabu Winoto to spread the Larasmadya art form outside the palace.

In 1939, by mandate from Kraton Kasunanan Surakarta, Moh. Salman was appointed as teacher at Ambang Ulum, a private elementary school affiliated to Islam. The school name were then changed to Madrasah Ibtidayah of Surakarta City. It is now located in the south of the Great Mosque of Agung or to the north of the Klewer Market. After Indonesia became an independent country, by request of the Indonesian government, Moh. Salman was transferred to Kantor Jawatan Agama (the government office dealing with religious affairs) with the main job of being a naib dealing with moslim marriage matters.

He worked for Kantor Jawatan Agama until he retired in 1974. However, Moh. Salman had various experiences in doing that by being transferred from one location to another. He worked in Surakarta from 1945 to 1954, in Playen, Wonosari, from 1954 to 1957, in Yogyakarta from 1957 to 1959, in Prambanan from 1959 to 1962, and in Sleman from 1962 to 1974 . In
Surakarta, Wonosari, Yogyakarta, and Prambanan, he remained a naib. However, when was assigned to the same office in Sleman, he was placed in a position dealing with the social field.

Moh. Salman spent the night at the homes of three fellow employees, which live nearby Kantor Jawatan Agama. Those fellow employees were Suko Sumadi, Susilo Widarto, and Sudjadi. Whenever Moh. Salman spent the night at the home of any one of those three, he was often asked to give a pengajian (a meeting for an Al-Qur'an recitation and discussion). For Moh. Salman with his capacity as mubaligh and Larasmadya expert, it was a golden opportunity to perform some dakwah of Islam. The pengajian usually lasted from 8 to 10 p.m. After the program of pengajian ended for the night, the participants did not directly excused themselves to go back to their respective homes. They remained a while to talk to each other. In such occasion, Moh. Salman raised the idea that spending the afternoon having practice in Larasmadya would be better than just taking a nap.

Moh. Salman's thinking was simple, that when there was a regular Larasmadya performance in a village, in time people would become interested in it and their ibadah (worship of God) would increase considering that Larasmadya was a Javanese musical art form with influence from Islam. By means of forming a Larasmadya group, Moh. Salman hoped to be able to get close to the jamaah (audience or congregation) of the pengajian and simultaneously get close to those without enough spirit for ibadah. His idea was accepted by the whole jamaah of the pengajian. The first practice in Larasmadya was held at Suko Sumadi's home at the village of Sucen attended by around twenty-five people consisting of those who were members of the jamaah of the pengajian and those who were not. The next practice was held at A. Susilo Widarto's home. And so on the practice was held in turns at Suko Sumadi's and

\section{a. Susilo Widarto's homes.}

In not more than three months' time, the practice in Larasmadya in the village of Sucen bore fruit in the sense that many members of the group were already able to play a part in Larasmadya, whether by playing the musical instruments or by presenting the vocals. It was considered meaning that a Sucen Larasmadya group was already established and the practice continued being held once every thirty-five days (always in the eve of a Friday coinciding with a Pon day in the Javanese market calendar), with the homes of the group members in turns as the place. Besides the routine practice, the Sucen Larasmadya group was ready to be invited to perform in commemoration of people's various special occasions of bubaran, supitan, sepekanan manten, mitoni, nyewu, wetonan, and others. When a Larasmadya group established itself in a village, the community supporting it transmitted the news to another village. 


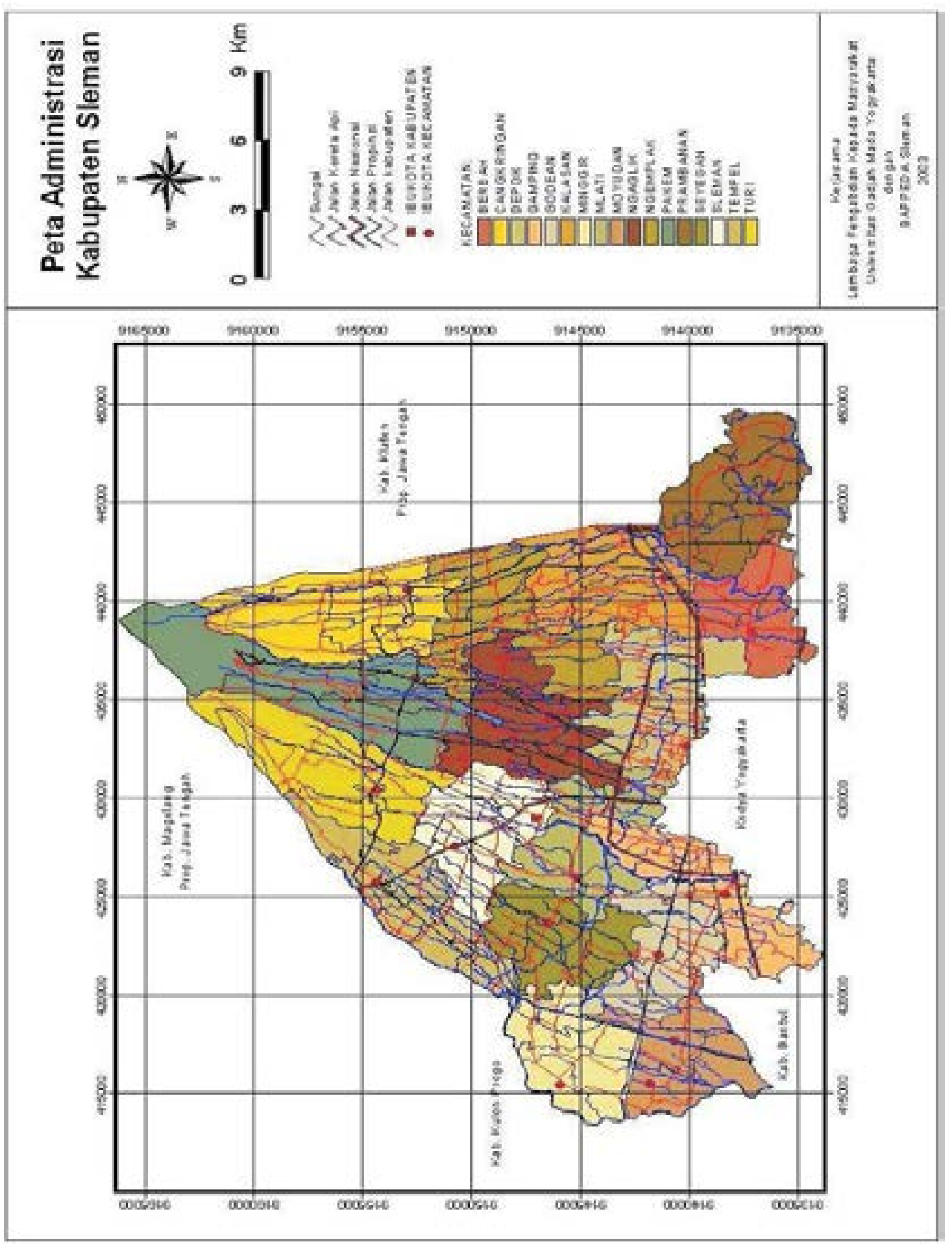

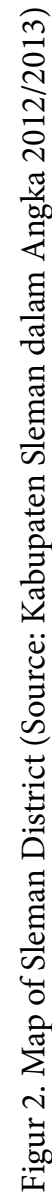


At present, the Larasmadya art form has been spread out to almost all of the subdistricts in the Sleman geocultural region, namely Sleman, Prambanan, Kalasan, Berbah, Cangkringan, Pakem, Turi, Mlati, Tempel, Seyegan, Godean, Moyudan, Gamping, Ngaglik, and Minggir subdistricts. People of Sleman have even spread it out of their region to Kulonprogo and Magelang. Such was the dissemination process of Larasmadya from Surakarta to the Sleman region.

Any manuscript about Larasmadya as an art form not from Sleman but from Surakarta in origin could also be traced. In the Sanapustaka library at Kraton Surakarta, there is a manuscript named Serat Larasmadya which turns out to be a copy. It explains that its original author is unknown (or anonymous); it was rewritten by Kartasmara in Surakarta from 1893 to 1939. The manuscript contains twenty-seven songs in Larasmadya written in Javanese orthography. Serat Larasmadya has been recorded in microfilm and is already included among the manuscripts mentioned in a list in a catalogue composed by Florida [1993].

Kuntowijoyo [1986/1987], reporting his research in Sleman, mentions the existence of a Larasmadya group which in its presentation uses as musical instruments terbangs, kendhangs, small sarons with two tone slats, and small kenthongans. This art form is also called Slawatan but the text is from Serat Wulangreh written by Paku Buwono IV and contains advice related to religion and nobility of character. Kuntowijoyo assumes that the Larasmadya art form in the Special Region of Yogyakarta and especially in the Sleman region is influenced by art forms from Surakarta because Sleman borders Surakarta.

\section{a. The Set of Larasmadya Musical Instruments}

There are four types of musical instruments used in a performance of Larasmadya (Figure 2). They are (1) terbang kempul, with a membrane diameter of around $40 \mathrm{~cm}$, (2) terbang gong, with a membrane diameter of around $50 \mathrm{~cm},(3)$ kendhang batangan or kendhang ciblon, and (4) kenthing (or thingthong), with two tone slats.

\section{b. The Larasmadya Text}

In each performance of Larasmadya, the performers use copies of a handbook containing the songs named Wulang Reh, salawat, and santi. In the text of Larasmadya, only the lyrics are presented; there is no musical notation and nothing to show how they are sung. The songs are included among the vocal elements of performances in the Javanese karawitan art family, especially that using the Surakarta style.

\section{c. The Larasmadya Stage}

The stage (or arena) for a performance of Larasmadya is usually the floor of a house. The performers could just sit cross-legged on a woven mat (or a carpet) laid out on it by the host. A mat laid out for a Larasmadya presentation is around 3 by $8 \mathrm{~m} 2$ in area to receive around twenty performers. When the performance is held indoors, the room used should be sufficiently spacious because it is used to accommodate not only the performers of Larasmadya but also the guests to the house. Basically, the Larasmadya art form could be presented in various places such as a room in a house, the ante-chamber of a mosque, an open field, a pendopo, an outdoor stage, an indoor stage, and a proscenium. The important thing is that the place used for presentation could contain relatively comfortably all the performers of a Larasmadya group.

\section{d. The Performers' Dress}

Performers in a Larasmadya group might use a very simple way of dress as their working uniform, consisting of a black peci, a koko shirt or any long-sleeved shirt, a sarong, and sandals or slippers (Figure 3). As for the sarong, the motif is free: checkered, striped, batik, or any other. Basically, the clothes worn by the Larasmadya performers above are those of male moslims. Besides, as their uniform, Larasmadya performers could also wear ethnic or traditional Javanese clothing consisting of a blangkon as headdress, a sorjan as shirt, a jarik as sarong, and slippers. This type of clothing is like that worn by the abdidalems (or employees) of Kraton Yogyakarta.

\section{e. The Number of Performers}

The number of performers involved in a presentation of the Larasmadya art form is around twenty per group. Almost all (or 90\%) of them are farmers. The rest consists of teachers, employees of state or private companies, and free workers of odd jobs. The farmers are the people keeping the Larasmadya art form alive without having to wait for the period of pause in farmwork while waiting for the crop to be ready for harvest. It is different in the case of Bakumpai farmer community members, who do non-farming activities during the period of pause in farmwork while waiting for harvest time [Wahyu and Nasrulah, 2012].

The communities supporting the Larasmadya art form at present developing in the Sleman geocultural region were at first largely members of the communities supporting the Slawatan Maulud art form who have done the social action of conversion by leaving it and moving into their present communities supporting the Larasmadya art form. Of course there is certain rationality in the conversion from the Slawatan Maulud art form into the Larasmadya art form up to now.

In the musical aspect, there are characteristics of Islamic music. One characteristic is the presence of the musical instrument called rebana or terbang. The musical instrument rebana could be found in any set of Islamic musical instruments all over the world and particularly in countries whose inhabitants embrace Islam, whether as a majority or a minority. Al Faruqi [1986] mentions that the musical instrument rebana is 
found in all the seven regions of the world. However, in different countries it might be called with different names. It is called duff in Arab, duba in Ethiopia, naha in Sudan, naqqarah in Khurdistan, naggara in Myanmar, and malay tambourine or kompang in Malaysia, for example. In Indonesia, especially in different regions, this musical instrument also has different names. For example, it is called rapai in Aceh, rebana in Riau, indhung in Jawa Barat, terbang in Jawa Tengah, and trebang in Jawa Timur. In the Sleman geocultural region especially, it is called terbang. However, there are also some people of the region who call it rebana; they are especially those who are not natives of the region. Though it has different names, as an Islamic musical in strument its form and function are the same. Rebana is considered an Islamic musical instrument because it is found in sets of equipment for Islamic performance arts only.

Likewise, the Larasmadya art form also uses the musical instrument rebana, in the case here known more as terbang (Figure 2). It uses two types of terbang called terbang kempul and terbang gong, so that the music in the Larasmadya art form could also be categorized as Islamic music Malm [1977]. Moreover, it is accompanied with text about salawat Nabi, the oneness of God, and morals.. In addition, the set of musical instruments in the Larasmadya art form is still added to with the musical instrument known as the Javanese kendhang, which makes the Islamic nature of the Larasmadya art form become colored with the identity of Javanese tradition (Figure 3). It becomes the rationality of performers of the Slawatan Maulud art form who made the social action of conversion to the Larasmadya art form. The action was to adapt themselves to the Javanese musical instrument which had long settled down in Java. In addition, the people in the Sleman geocultural region who had long been familiar with the musical instrument kendhang Jawa would more quickly learn to perform the Larasmadya art form compared to how fast they would learn to perform the Slawatan Maulud art form with its musical instrumentation having the nuance of Arabic music.

The melody of the songs in the Larasmadya art form has the characteristics of being Islamic or, in short, is Islamic because there is a resemblance between it and the melody found in pujian Islam. Pujian in this case is a number of songs in Javanese or Arabic sung between adzan (first call to prayer) and qomat (second call) before salat jamaah (praying en masse) at the mosque. The songs are about the greatness of Allah, the noble character of Nabi Muhammad SAW, commands, threats, and warnings, and news of joy (Table 1). So the rationality (or reasoning) of the performers of the Slawatan Maulud art form for their social action of conversion to the Larasmadya art form was that it was for the purpose of adapting themelves and making it easier for them in learning Islamic musical art form. For one thing, the text used in the Larasmadya art form, which used the Javanese language and Javanese orthogaphy, was easier for them to cope with than the text used in the Slawatan Maulud art form, which used the Arabic language and Arabic orthography.

After an identification was made on the songs showing influence from Islam, inferences were made from the songs concerning which verses of the holy book Al-Qur'an and which principles in Hadist Prophet Muhammmad SAW that the songs were associated with. Through inferences, the songs with influence from Islam were put into groups on the basis of theories about the pillars of Islam. The pillars are upheld through four supporting elements, namely, (1) dakwah, (2) taklim, (3) zikir, and (4) akhlak.

The hope is that these pillars of Islam would be like the light of the sun, which keeps shining and would never cease even once (Ansari, 61-62). The parable is intended to tell that the four supporting elements upholding the pillars of Islam are amalans (practices) that should be kept up. (1) The pillar based on dakwah implies that moslims should believe in the oneness of Allah, as mentioned in the songs Mijil, Tepikawuri, and Purwangga. (2) The pillar based on taklim implies that moslims should read, study, and learn AL Qur'an and $\mathrm{Al}$ Hadits, as mentioned in the songs Asmaradana, Dandanggula, and Glathiglindhing. (3) The pillar based on zikir or ibadah implies that moslims should do the regular prayers at five certain times of the day, as mentioned in the songs Topengarum, Soyung, and Lambansari. (4) The pillar based on akhlak implies that moslims should be able to respect others, as mentioned in the songs Wirangrong, Pocung, and Man Dhoblang. These four pillars of deeds to practice as urged in the Larasmadya art form, in Rashid's view [2014], could be developed in the communities supporting it as expression of thankfulness to Allah the Almighty.

Besides supporting the pillars of Islam, the contents of some texts of the songs in the Larasmadya art form support the life of farmer communities (including those supporting the Larasmadya art form) in the sense that farming practices are based on adaptations from traditional production systems [Kapungwe, 2012] in the Sleman geocultural region. The texts meant here are found in, among others, the following songs.

1. Glele

Pungkas wana pajatenan, nampak tarataban grumbul, marga lempar wedhen mawur, ra ara rata awiyar, tarak antar nuju mangsa, sadaya tan na wahipun (bare land, land mounds are seen, broken road loose soil, uncultivated land spread, when season transition comes, it all produces nothing).

\section{Glele}

Nuju mangsa pakebonan, sabin-sabin katon subur, kumriciking belik kedhung, marga-marga mili toya, jawah rohmat kang tumiba, kodrata kang maha agung (when the season comes for gardening, fields for growing rice look fertile, sound of river flow, everywhere there is 


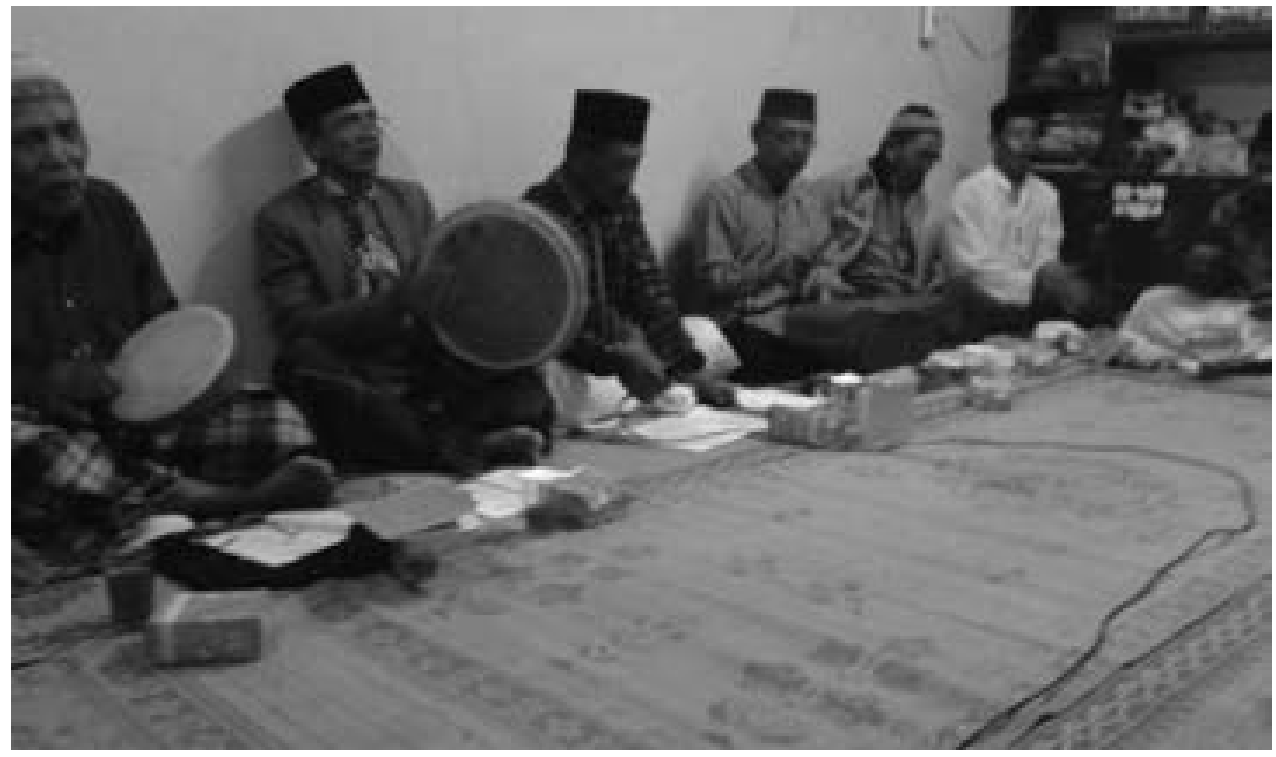

Figure 2. The Group of Larasmadya Art from Durenan, Triharjo, Sleman. (Photo: Sutiyono)

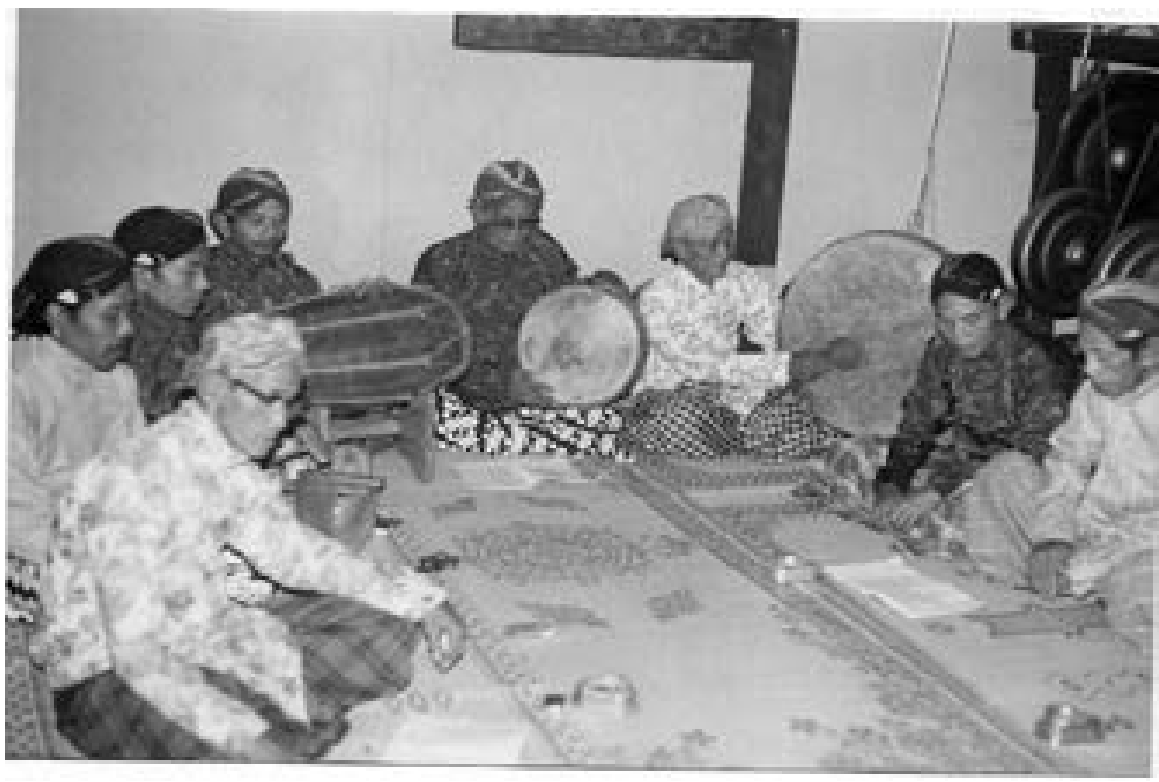

Figure 3. The Group of Larasmadya Art from Temulawak, Triharjo, Sleman. (Photo: Sutiyono)

Table 1. Differences Between the Slawatan Maulud and Larasmadya Art Forms

\begin{tabular}{|c|c|c|}
\hline Indicator of Difference & Art Form & \\
\hline & Slawatan Maulud & Larasmadya \\
\hline Musical Instrument & terbang & terbang, kendhang Jawa, saron \\
\hline & & Serat Wulangreh \\
\hline Text Material & Serat Al-Barjanji & \\
\hline & & Javanese \\
\hline Language of Text & Arabic & \\
\hline Content of Text & $\begin{array}{l}\text { Life Story of Nabi Muhammad } \\
\text { SAW }\end{array}$ & Pillars of Islam and Agriculture \\
\hline
\end{tabular}


water flowing, rain of blessing has come, the nature of Almighty God).

\section{Witing Klapa}

Witing klapa jawata ing ngarsa padha, salugune wong wanita, dhasar nyata kula sampun njajah praja, ing Ngayogya Surakarta (to begin life on the face of earth, is inseparable from women, it is a fact I have traveled the regions, in Yogyakarta and Surakarta).

\section{Dandanggula}

Datan mendhung miwah datan grimis, katon padhang langitnya sumiwak, rarasmadya suarane, anamabah asrining kampong, ngemu rasa anggugah ati, eling marang pangeran, sagunging tumungkul, jim setan miwah gandarwa, ilu-ilu thethekan lan banaspati, angendring padha lunga (no dark cloud and no drizzle, looks bright with the sky clear, the sounds of Larasmadya, increase the village beauty, a feeling awakens the heart, remembering God, all heads bow, jinn, Satan, and gendruwo, ilu-ilu thethekan and banaspati, all run away).

\section{Among Tani}

Amongtani amongtani cacah ana, wohing dhami pirakehe lan jenenge, sun arsa miyarsakake, parine tambak menur, Rajawlingi Jakabonglet pendhok wesi dhudha ngaksak, dhudha ngangsak ndulu randha menter-menter (Farmer folks, please note, how many rice grains planted and their names, I would like to witness, the rice plants grow more fertile, Rajawlingi and Jakabonglet by name, with iron tools widowers clear the fields, eyeing tantalizing widows the while).

The texts of the songs in the Larasmadya art form describe the life of the farmer communities supporting the art form in the Sleman geocultural region. A description of the Sleman geographical region in the song Glele, among others, mentions the presence of bare ground with soil mounds which means that there are still regions of wide grounds in Sleman not yet turned into farmland. However, it is still possible to turn the bare ground by means of intensification treatments into fields of growing rice plants with potential for increases in rice production in the course of improvement in regional food endurance [Widyatmoko, 2014]. It could be remembered that Sleman is said to be the center of rice storage in the Special Region of Yogyakarta Province.

In addition, the texts of the songs in the Larasmadya art form which describe the life of the farmer communities in the Sleman geocultural region mention water flowing freely from Mount Merapi, fertile farmland with rice, corn, salak pondoh, and tobacco plants, and rains and drizzles supporting agriculture. There is a mention of Sleman, the Special Region of Yogyakarta, being a region bordering Surakarta enabling people to mobilize from Yogyakarta to Surakarta and vice versa. Those examples of texts of the songs in the Larasmadya art form which support the life of the farmer communities in the Sleman geocultural region imply that the farmer communities formerly supporting the Slawatan Maulud art form made a conversion to the Larasmadya art form. It also proves that the Larasmadya art form has lived and developed in almost all the kecamatan regions in the Sleman regency up to now.

\section{Hidden Meaning Behind the Social Action of Conversion}

One of the walis (pioneering preachers) having a great share in conceiving the idea of making the Javanese culture become the medium to incorporate elements of Islam was Sunan Kalijaga. He was considered intelligent in fusing the values of Islam with the Javanese culture so that the Javanese people enthusiastically sympathized with the approach to dakwah of Islam used by Sunan Kalijaga. The slow and gradual penetration of Islam values into Javanese culture was the method adopted by Sunan Kalijaga to spread dakwah of Islam to various regions in Java. The slow and gradual penetration also proved that dissemination of Islam was not radically conducted; instead, dakwah of Islam was done moderately (in a soft way), filled with coolness and friendliness, and peacefully. Here the process of making Islam cease being a stranger to be welcomed and become native could run gently without causing social unrest.

For the circles of ulamas (religious scholarsleaders), dakwah of Islam is good when it does not use violent ways. It should be done with the consideration that it would give wisdom to society. The Javanese society with its various local culture is not an easy problem for one to be faced with. The Javanese culture already in a settled state in various village areas, and has been existed for tens of thousands of years. It is admitted that slowly the Javanese culture has changed like a flowing water.When Hinduism and Buddhism entered Java, they greatly influenced and made changes in the Javanese culture. But the changes were very soft and gentle and seemingly did not cause any sharp unrest.

Utilizing culture for the interest of dakwah Islam is a form of very soft, very gentle dakwah. The walis brought in values of Islam through the means of culture symbolically. That is what makes ulamas consider that the walis' dakwah was very soft, very gentle. It was like catching fish in a certain way. The fish could be caught but it does not cause any cloudiness in the water and the water remains clear.

According to traditional ulamas, the walis' dakwah was extremely fair and wise. Likewise, in considering the Javanese culture when making their dakwah, individuals of the group called Walisongo were also fair and wise in attitude. They were being fair and wise is in the sense that they did not move away the whole treasury of local culture. There was some people which 
was left alone to continue developing by itself but there was also some which was infused with Islam values. The Walisongo group were also willing to accept the Javanese culture as part of the walis' living within a society. With their concept of being fair and wise, they could get along freely with the Javanese society. It gave them an opportunity to gradually give dakwah to the Javanese society.

The traditional group highly praises the walis' dakwah by revealing evidence that the walis' presence with their various strategies of dakwah could convert the whole island of Java into Islam. The walis are regarded as pioneers of dakwah Islam in Java. Had they been absent, Java at present would possibly be still inhabited by a society embracing animism, Hinduism, and Buddhism. The walis played their part as those who accomplished the process of making Islam welcome and become native in Java.

Several matters are closely attached to Islam that has become native [Rahmat, 2003]. First, it is contextual in the sense that it is understood as a teaching related to the context of the times. Change in time and difference in region become the key to the work of interpretation and ijtihad (personal reasoning). Thus, Islam would be capable to keep renewing itself and to be dynamic in responding the changes of times. In addition, Islam would be capable to flexibly hold dialogues with the condition of society that varies from one to another.

Second, it is tolerant in the sense that the contextuality of Islam, in turn, causes the realization that variety in the interpretation of Islam is not a deviation when the thinking work is done responsibly. Thus, this attitude would produce a tolerant attitude toward various differences in interpreting Islam. Furthermore, awareness of the reality of the context concerning the plural nature of being Indonesian or Javanese also demands a sincere admission of the equality of religions with all its consequences. It was this spirit of diversity which became the pillar of Indonesia's birth.

Third, Islam respects tradition in the sense that when one recalls that Islam on the days of the Prophet Muhammad SAW was also built up on old (Arabic) tradition which was good, one realizes that it proves that Islam does not always regard local culture as enemy. So, instead of being considered an enemy, local culture becomes a means of vitalizing Islam values because those values need a frame which is intimate with the living of those who embrace the religion. Art is a means of communicating with other people because it directly provides conceptual communication between people [Mahdavinejad, 2014]. In this context, the Larasmadya art form could be used as effective means of communication to incorporate Islam values into society. Thus, the meaning implied behind the social action of conversion by the communities supporting the Larasmadya art form is a process of making Islam cease being a stranger to be welcome and become native in the Sleman geocultural region through the
Larasmadya art form. This process of making Islam native is also related to presenting the geography of Islam [Buang, 2014] ; the relation is through relevance with the context of moslems.

\section{Conclusion}

Both the Slawatan Maulud art form and the Larasmadya art form are considered Islamic music in view of the fact that in their presentations they involve (1) an Islamic musical instrument and (2) Islamic text. The musical instrument meant here is the one called the terbang or the rebana. It is a fact that such an instrument is found in countries whose people embrace the religion called Islam and also it is the instrument always used in the orchestration or set of musical instruments in artistic performances showing Islamic influence.

The Larasmadya art form uses a particular text titled Serat Wulang Reh. The text contains Javanese songs showing influence of Islam. Inferences were made from these songs about which verses in the holy book Al-Qur'an and which principles in Hadist Nabi Muhammmad SAW that the songs were associated with. By way of inference, the Javanese songs with influence of Islam are grouped according to the pillars of Islam, which are upheld through, among others, four support elements, namely, (1) dakwah, (2) taklim, (3) zikir, and (4) akhlak.

In addition, the text of the songs in the Larasmadya art form also describes the life of the farmer communities supporting the Larasmadya art form in the Sleman geocultural region. It implies that the farmer communities that used to support the Slawatan Maulud art form have made a conversion to the Larasmadya art form. It also proves that the presence of the Larasmadya art form in the Sleman geocultural region is for the reason that it fulfils the needs and fits the condition of the farmer communities in Sleman. More importantly, the meaning of the social action of conversion by the farmer communities that were former supporters of the Slawatan Maulud art form later becoming supporters of the Larasmadya art form is that it is a form of making Islam cease being a stranger to be welcome and become native in the Sleman geocultural region through the Larasmadya art form.

\section{Acknowledgements}

The writer thanks the regional government authorities of the Sleman regency for having provided considerable geographical data of the Sleman region. In addition, many thanks are also attributed to informants in the field who are mostly head officials of the association of the Larasmadya groups throughout the Sleman regency. They have provided highly valuable data for the research. 


\section{References}

Al Faruqi, I.R. and Louis Lamya Al Faruqi. (1986), The Cultural Atlas of Islam. New York: Macmillan Publishing Company.

Ansari, F.A.t.t. Pedoman Bertabligh. Penang (Malaysia): Fazal Mohammed Bros.

BPS Kabupaten Sleman (2014), Kabupaten Sleman Dalam Angka 2014. Sleman: Badan Pusat Statistik Kabupaten Sleman.

BPS Kabupaten Sleman (2013), Kabupaten Sleman Dalam Angka 2012/2013. Sleman: Badan Pusat Statistik Kabupaten Sleman.

Buang, A (2014), "Islamic human geography - Making space for a conver sation of difference". Geografia: Malaysian Journal of Society and Space, Vol. 9, Vol. 4., pp., 128-141.

Florida, N.K. (1993), Javanese Literature in Surakarta Manuscripts (I). Ithaca, New York: Cornell University Press.

Heckathorn, D. (2001), Sociological Rational Choice, dalam George Ritzer dan Barry Smart (ed). Hand Book of Social Theory. London: Sage.

Kapungwe, E M(2012), Traditional Farming Pracyices and Wasterwater Irrigation Farming in Periurban, Zambia. Indonesian Journal of Geography, Vol. 44, No. 2, December pp., 103-119.

Koentjaraningrat (1990), Pengantar Ilmu Antropologi. Jakarta: Rineka Cipta.

Kuntowijoyo (et al.). (1986/1987), Tema Islam dalam Pertunjukan Rakyat Jawa: Kajian Aspek Sosial, Keagamaan, dan Kesenian. Yogyakarta: Proyek Studi dan Pengkajian Kebudayaan Nusantara (Javanologi).

Mahdavinejad, M. (et. al.). (2014), “The Functions of Art in Conveying the Meanings to Audience (Case Study: Some Selected Images from the Earthquake of Bam, 2003)". American Journal of Educational Research, 2014, Vol. 2, No. 2, pp., 66-72.

Malm, W.P. (1977), Music Cultures of The Pacific, The Near East, and Asia. Englewood Clifs, New Jersey: Prentice Hall.

Morison, K. (1995), Marx, Durrkhiem, Formations of Modern Social Thought. London: Sage.
Murgiyanto, S. (1993), Tradisi dan Inovasi Beberapa Masalah Tari di Indonesia. Jakarta .

Parsons, Talcott. (1974), The Structure of Social Action. New Yok: The Free Press.

Rahmat, M. Imdadun. (2003), Islam Pribumi: Mendialogkan Agama Membaca Realitas. Jakarta: Erlangga.

Rashid, A. Abd. (2014), Islamic Paradigms for Momen,s Education and Their Roles to Bring up Tawhidic Ummah (Belived Nation). Asian Journal of Management Sciences and Education, Vol. 32, No. 2, pp. 136-141.

Sedyawati, E. (1995), Keislaman dalam Tari di Indonesia. Makalah dipresentasikan pada Seminar Nasional Islam dan Kesenian di Universitas Ahmad Dahlan Yogyakarta, 10-11 Juni.

Soedarsono (1994), Religious Musics in Indonesia. Makalah dipresentasikan dalam First Conference and Festival of asia-Pasific Society for Ethnomusicology, Soul, 13-19 November.

Suwarno, P.J. (et. al). (2002), Kabupaten Sleman dalam Lintasan Sejarah. Sleman: Humas Sekretariat Daerah Kabupaten Sleman.

Wahyu and Nasrulah. (2012), Kearifan Lokal Petani Dayak Bakumpai Dalam Pengelolaan Padi di Lahan Rawa Pasang Surut, Jurnal Komunitas, Vol. 4, No. 1, pp., 36-45.

Waters, M. (1994), Modern Sociological Theory. London: SAGE Publications.

Widyatmoko (et. al)/. (2014), Land use planning of Paddy field using geographic information system and land evaluation in West Lombok, Indonesia. Indonesian Journal of Geography, Vol. 45, No. 1, pp. 89-98.

(2014), Profil Kabupaten Sleman. (http://www.bpkp.go.id/diy/konten/830/ProfilKabupaten-Sleman).

..(2014), Map of Indonesia. The Sleman regency is north of Yogyakarta. Source: Noretzarea.blogspot.com 